Original Research Paper

\title{
Pembangunan Permainan Mudah Alih Matematik 'Sifir Run' untuk Pembelajaran Topik Darab bagi Murid Sekolah Rendah
}

\author{
Amira Mohd Ishak ${ }^{1}$, Mohd Hishamuddin Abdul Rahman ${ }^{2}$
}

${ }^{1}$ Program of Software Engineering, Department of Computing. Faculty of Art, Computing \& Creative Industry. Universiti Pendidikan Sultan Idris. Tanjong Malim, Malaysia.

${ }^{2}$ Department of Computing. Faculty of Art, Computing \& Creative Industry. Universiti Pendidikan Sultan Idris. Tanjong Malim, Malaysia.

\section{Article History}

Received:

14.11.2021

Revised:

14.12.2021

Accepted:

21.12.2021

*Corresponding Author:

Mohd Hishamuddin Abdul Rahman

Email:

mhishamuddin@fskik.upsi.edu.my

This is an open access article, licensed under: $\mathrm{CC}-\mathrm{BY}-\mathrm{SA}$
Abstrak: Bidang permainan mudah alih pada era ini telah melonjakkan evolusi pendidikan dan juga membangunkan kemahiran kognitif, spatial dan kemahiran motor (skill) serta meningkatkan kemahiran ICT. Pembangunan ICT dan teknologi telah memberi banyak peluang dan ruang untuk diterokai dalam bidang permainan mudah alih. Sifir Run merupakan sebuah aplikasi permainan mudah alih yang bertemakan pembelajaran sifir. Pembangunan aplikasi ini bertujuan untuk meningkatkan kemahiran menghafal sifir dalam kalangan murid sekolah rendah. Objektif projek ini adalah untuk mengenalpasti permasalahan murid dalam operasi darab, mereka bentuk dan membangunkan permainan mudah alih yang bertemakan sifir dan mengkaji kebolehgunaan aplikasi permainan mudah alih tersebut. Pembangunan aplikasi ini dijalankan dengan menggunakan model ADDIE. Terdapat seramai 20 orang responden dipilih oleh pengkaji bagI menjalani fasa penilaian untuk menguji kebolehgunaan aplikasi permainan mudah alih Sifir Run.

Kata Kunci: Pendaraban, Permainan Komputer Mudah Alih, Permainan Pendidikan.

Development of 'Sifir Run' Mathematical Mobile Game for Learning Multiplication Topics in Primary School Students

Abstract: The field of mobile games in this era has accelerated the evolution of education and also developed cognitive, spatial and motor skills (skills) as well as improve ICT skills. The development of ICT and technology has provided many opportunities and spaces to be explored in the field of mobile gaming. Sifir Run is a mobile game application themed on learning ciphers. The development of this application aims to improve the skills of memorizing ciphers among primary school students. The objective of this project is to identify students' problems in multiplication operations, design and develop cipher -themed mobile games and study the usability of such mobile game applications. The development of this application was carried out using the ADDIE model. A total of 20 respondents were selected by the researcher to undergo the evaluation phase to test the usability of the Sifir Run mobile game application.

Keywords: Educational Games, Mobile Computer Games, Multiplication. 


\section{Pendahuluan}

Seiring dengan dunia teknologi yang kian pesat pada saat ini, bidang permainan mudah alih sudah semakin meluas dan semakin digemari oleh masyarakat terutama golongan kanak-kanak dan remaja. Permainan mudah alih pada dasarnya bersifat hiburan kerana pemain akan berasa gembira apabila bermain permainan tersebut. Dalam era ini, permainan mudah alih mempunyai kualiti dan visualisasi yang cukup canggih kerana disokong oleh teknologi yang maju sehingga pemain lebih saling interaktif dan terasa hidup dalam permainan tersebut. Oleh itu, boleh dikatakan bahawa permainan mudah alih semakin berkembang seiring dengan ledakan teknologi pada masa kini. Menurut Kerr \& Ivory [1], pada hari ini, permainan dalam peranti mudah alih secara seriusnya mencabar PC dan permainan konsol. Aplikasi-aplikasipermainan dalam rangkaian tanpa wayar menerusi permainan mudah alih telah mempengaruhi dan membentuk budaya hiburan dalam konteks yang terkini. Selain untuk tujuan berhibur, permainan mudah alih yang berkonsepkan pengajaran dan pembelajaran juga sudah semakin banyak dibangunkan. Aktiviti bermain dapat dilakukan secara maksimum dalam proses pengajaran dan pembelajaran melalui penggunaan teknologi yang semakin canggih dan mudah digunakan. Berbanding kaedah konvensional, permainan mudah alih telah dijadikan sebagai salah satu platform terbaik yang berpotensi menggalakkan perkembangan kognitif dan pembelajaran kanak-kanak setelah industri permainan mudah alih mengalami perkembangan yang pesat. Kemajuan dan penularan penggunaan Teknologi Maklumat dan Komunikasi (ICT) dalam masyarakat membawa maksud bahawa sistem pendidikan di rantau ini semakin memanfaatkan ICT dalam mengendalikan banyak cabaran yang timbul yang dihadapi oleh sistem pendidikan di seluruh dunia [2] [3].

Bidang permainan mudah alih pada era ini telah melonjakkan evolusi pendidikan dan juga membangunkan kemahiran kognitif, spatial dan kemahiran motor (skill) serta meningkatkan kemahiran ICT. Pembangunan ICT dan teknologi telah memberi banyak peluang dan ruang untuk diterokai dalam bidang permainan mudah alih. Kaedah permainan mudah alih telah diadaptasikan dalam sistem pendidikan pada masa ini bagi tujuan menarik minat para pelajar untuk belajar secara pendekatan baharu [4]. Permainan mudah alih yang berasaskan pembelajaran dapat membantu pelajar untuk tampil kreatif dengan meneroka dan berfikir secara kritis untuk mendapatkan maklumat tambahan supaya pemain boleh maju ke peringkat seterusnya.

Dalam menggunakan teknologi dalam pengajaran dan pembelajaran, apa yang lebih utama ialah bagaimana teknologi itu digunakan dalam membantu meningkatkan cara berfikir pelajar [5]. Dengan pendekatan yang betul, pelajar dapat memanfaatkan penggunaan teknologi untuk menyelesaikan masalah dalam kerja-kerja seharian mereka [6]. Penggunaan teknologi dapat memberikan ruang dan peluang kepada pelajar untuk meneroka alam sebenar atau simulasi dengan aplikasi yang telah direka, tambahan pula dengan teknologi Internet, pelajar dapat berinteraksi secara masa nyata dengan rakan mereka dan pembelajaran akan menjadi lebih interaktif [7]. Permainan mudah alih yang khusus dalam subjek tertentu juga semakin banyak dibangunkan untuk memastikan pemain memberikan tumpuan terhadap subjek tersebut sehingga pemain dapat menguasai pembelajaran dalam permainan mudah alih itu [8]. Sebagai contoh, pelbagai permainan mudah alih yang memfokuskan Matematik boleh didapati di Play Store seperti Math Games, Math Kids, Math Master dan sebagainya. Dengan adanya permainan mudah alih yang berasaskan pengajaran dan pembelajan seperti ini, pelajar dapat mempraktikkan apa yang dipelajari dalam permainan yang nyata [9] [10].

Menurut Yong [11], kebolehan Matematik yang lebih tinggi adalah bergantung kepada kebolehan yang lebih rendah iaitu dalam bentuk hierarki. Murid perlu mempunyai pengetahuan dalam peringkat sebelumnya supaya dapat menguasai matapelajaran Matematik di peringkat yang lebih tinggi. Jika tidak, murid akan mengalami kesukaran untuk mahir dalam matapelajaran tersebut [12]. Menurut Meerah [12], faktor utama yang menentukan keupayaan atau prestasi seseorang murid pada satu tahap pembelajaran ialah penguasaan konsep asas yang kukuh dan mencukupi semasa mengikuti pembelajaran tersebut. Ramai murid yang tidak dapat menyelesaikan masalah dalam Matematik kerana penguasaan konsep sebenar yang lemah atau berlakunya kesalah fahaman konsep [13]. Seseorang murid perlu memahami dan menguasai setiap langkah yang terlibat sebelum beralih ke satu tahap pembelajaran yang baru kerana isi pelajaran Matematik mempunyai konsep yang berstruktur dan berhierarki.

Konsep pendaraban merupakan antara konsep yang paling penting dalam Matematik. Ia merupakan topik yang terkandung dalam asas kemahiran Matematik iaitu tambah, tolak darab dan bahagi. Kepentingan kemahiran ini jika tidak dikuasai oleh pelajar pada peringkat sekolah rendah, natijahnya akan membantutkan penguasaan kemahiran-kemahiran Matematik pada peringkat yang lebih tinggi. Permasalahan dalam operasi mendarab lebih mudah diselesaikan sekiranya mereka menghafal sifir. Seperti mana yang kita ketahui, operasi darab menjadikan pengiraan kita lebih mudah dan cepat 
berbanding dengan hanya menggunakan operasi penambahan.

Ketika di peringkat rendah, murid mampu menguasai operasi tambah dan tolak dengan mudah. Hal ini kerana konsep tambah dan tolak ini mudah difahami dan dikuasai. Selain guru di sekolah, ibu bapa juga mampu mengajar dan menerangkan konsep ini kepada anak-anak di rumah. Pada saat ini, murid cukup berminat dengan matapelajaran Matematik kerana ia mudah dan menyeronokkan. Namun apabila mereka mula mempelajari operasi darab yang memerlukan mereka menguasai sifir, kepayahan dan kesukaran mula terasadalam matapelajaran ini kerana ia memerlukan pelajar berfikir untuk memahami konsepnya. Operasi darab memerlukan pelajar memahami konsep asas pendaraban dan seterusnya menguasai sifir yang merupakan komponen utama dalam pembelajaran ini. Kesukaran akan bertambah apabila mereka mula mempelajari pendaraban yang melibatkan dua digit, tiga digit dan seterusnya. Kesukaran Matematik yang dihadapi di peringkat rendah persekolahan sering berterusan ke alam persekolahan pada peringkat menengah. Oleh itu, murid perlu memahami dan menguasai asas kemahiran Matematik sejak peringkat sekolah rendah lagi. Mereka perlu singkirkan persepsi negatif terhadap matapelajaran Matematik dan mempelajarinya dengan pendekatan yang lebih menggembirakan dan memudahkan mereka. Bagi mengatasi masalah ini, aplikasi permainan mudah alih yang bertemakan sifir iaitu Sifir Run difikirkan dapat membantu murid di peringkat sekolah rendah agar mereka dapat mengasah kemahiran menghafal sifir dengan betul dan pantas. Murid akan dapat mempelajari sesuatu sambil bermain. Dengan ini, mereka tidak akan mudah tertekan dan dapat mempelajari matapelajaran Matematik dengan tenang dan menggembirakan. Antara dasar itulah, permainan mudah alih yang bertemakan sifir ingin dibangunkan dan mensasarkan pemainnya dari golongan murid sekolah rendah.

\section{Kajian Literatur}

\subsection{Permainan Digital}

Menurut kamus Dewan Bahasa Melayu Edisi Kedua, permainan didefinisikan sebagai perbuatan atau hal bermain. Permainan adalah sebahagian dari bermain dan bermain juga sebahagian dari permainan. Kedua-duanya saling berhubungan dan permainan merupakan kegiatan kompleks yang didalamnya terdapat peraturan dan budaya [14]. Aplikasi permainan dapat dijalankan dalam pelbagai platform, antaranya komputer peribadi, telefon pintar dan tablet. Permainan merupakan suatu sistem yang memiliki peraturan tertentu dimana pemain akan terlibat dalam suatu permasalahan sehingga dapat menghasilkan suatu kemenangan atau kekalahan. Dalam permainan digital, terdapat beberapa jenis permainan dan ianya dikategorikan berdasarkan jenis platform atau alat yang digunakan untuk bermain permainan tersebut. Antaranya ialah arcade games, pc game, handheld games dan mudah alih games. Permainan bukan sahaja dijadikan sebagai hobi ataupun untuk mengisi masa lapang, ia juga dapat digunakan dalam pembelajaran untuk meningkatkan kreativiti dan intelektual pemain [15].

\subsection{Permainan Mudah Alih}

Permainan mudah alih boleh didefinisikan secara meluas sebagai permainan yang direka untuk peranti mudah alih, seperti telefon pintar, feature phones, pocket PCs, PDA, tablet PCs dan pemain media mudah alih. Permainan mudah alih terdiri daripada permainan asas (seperti Ular pada telefon lama Nokia) kepada yang lebih canggih seumpama 3D dan augmented reality games [16] [17] [18] [19] [20] [21] [22] [23] [24].

Keseronokan dalam budaya berhibur yang melibatkan teknologi peranti mudah alih telah menjadikan permainan mudah alih popular di kalangan pengguna termasuk kanak-kanak. Dalam permainan, terdapat beberapa genre yang merupakan format atau gaya dari sesebuah game. Antara genre dalam permainan ialah actions game, strategy games, role-playing games, real-world simulations, construction and management games, adventure games, puzzle games, educational games and casual games [25]. Permainan mudah alih yang telah dibangunkan oleh pengkaji iaitu Sifir Run merupakan permainan dari genre educational games atau permainan pendidikan. Hal ini kerana dalam permainan Sifir Run terdapat elemen-elemen pembelajaran yang bertujuan untuk mengasah kemahiran berfikir dan kemahiran menghafal pemain.

\subsection{Perbandingan Platform antara Permainan Konsol, Permainan Mudah Alih dan Permainan PC}

Dalam ilmu komputer, platform atau serambi merupakan gabungan dari sebuah senibina perkakasan dan rangka kerja perisian termasuk kerangka aplikasi [26]. Platform merupakan elemen penting dalam sesebuah pembangunan perisian. Platform boleh ditakrifkan sebagai tempat untuk menjalankan perisian. 
Platform permainan merupakan tempat untuk menjalankan atau memainkan sesebuah permainan yang dibangunkan. Antara contoh platform permainan ialah permainan konsol, permainan mudah alih dan permainan PC. Platform tersebut merupakan platform yang popular digunakan pada masa kini. Permainan dimainkan bertujuan untuk menghiburkan para pemain. Terdapat pelbagai permainan yang menarik dari pelbagai jenis platform pada era ini. Pengguna hanya memerlukan jaringan internet danperanti untuk memuat turun permainan yang boleh didapati di pelbagai aplikasi store dan laman web. Setiap platform memiliki permainan mereka tersendiri dengan ciri spesifik yang mempunyai kebaikan dan keburukan masing-masing.

Menurut kajian yang dijalankan oleh Galehantomo [27], permainan konsol adalah permainan video dimana pengguna menggunakan konsol khas untuk bermain. Sebagai contoh yang paling popular ialah PlayStation. Permainan konsol mempunyai pelbagai kelebihan seperti mempunyai pengawal khas atau kayu bedik (joystick) untuk bermain permainan dan setiap permainan konsol mempunyai kayu bedik yang berlainan. Selain itu, permainan konsol tidak menggunakan cable controller dan mempunyai sistem yang boleh digunakan untuk melayari internet. Walaubagaimanapun, permainan konsol juga memiliki kekurangan iaitu sukar untuk membawa ke tempat lain kerana ia memerlukan tenaga elektrik yang berterusan dan televisyen sebagai media utama untuk dimainkan, harga permainan konsol juga sangat mahal berbanding platform lain dan permainan yang disediakan untuk permainan konsol juga sangat mahal berbanding permainan di platform lain [27].

Seterusnya, permainan mudah alih adalah permainan video dimana pengguna penggunakan telefon pintar atau media PDA. Menurut Geraldus Galehantomo lagi, permainan mudah alih mudah untuk dibawa kemana sahaja kerana ia mempunya bateri dan boleh dicas semula dan saiznya yang kecil mudah untuk disimpan. Kebiasaanya, permainan yang disediakan juga percuma dan jika ada yang berbayar, harganya tidak mahal. Namun, terdapat juga beberapa keburukan dalam permainan mudah alih iaitu kualiti grafik kurang menyokong berbanding platform lain dan permainan dalam permainanmudah alih juga mudah mendapat ralat berbanding permainan dalam platform lain.

Menurut kajian Geraldus Galehantomo, permainan PC adalah permainan video dimana pengguna menggunakan komputer atau laptop sebagai alat untuk bermain. Antara kelebih bermain permainan menggunakan platform permainan PC ialah mempunyai Game Engine yang boleh diubah jika terdapat ralat atau kesilapan perisian, mempunyai grafik PC terbaik dari semua platform dan tiada sekatan untuk memainkannya dengan menggunakan PC kerana semua peranti boleh ditingkatkan. Keburukan dalam permainan PC menurut kajian yang dilakukan oleh Geraldus Galehantomo ialah ia tidak mudah alih kerana menggunakan komputer, elektrik yang digunakan untuk bermain sangat tinggi dan lebih rumit untuk memperbaiki dari kerosakan.

\subsection{Permainan Pendidikan}

Pembelajaran yang berasaskan permainan merupakan salah satu usaha untuk menarik minat pelajar untuk mempelajari sesuatu perkara baru dan ianya juga merupakan pembelajaran berpusatkan kepada pelajar untuk bermain permainan bagi tujuan pendidikan. Dengan menggunakan permainan dalam pendidikan, para pelajar lebih berpotensi untuk membina maksud dan pemahaman dalam setiap fasa pembelajaran [28] [29] [30] [31] [32] [33]. Permainan pendidikan iaitu suatu kegiatan yang sangat menyenangkan dan merupakan cara atau alat pendidikan yang bersifat mendidik. Permainan pendidikan adalah sebuah permainan yang digunakan dalam proses pembelajaran dan dalam permainan tersebut mengandungi unsur mendidik dan nilai-nilai pendidikan. Permainan pendidikan merupakan pembelajarantidak formal yang melibatkan teknologi dalam pendidikan. Permainan pendidikan juga merupakan bahan bantu mengajar untuk belajar tanpa paksaan sehingga ia memberikan kesan yang positif dalam pembelajaran. Kaedah pembelajaran berasaskan permainan berupaya menarik perhatian pelajar untuk melibatkan diri dalam proses P\&P secara aktif.

Menurut Rais [34], permainan pendidikan adalah permainan yang khusus dirancang untuk mendidik pemain tentang sesuatu pembelajaran, pengembangan konsep dan pemahaman serta membimbing dalam melatih kemampuan dan memotivasikan pemain untuk memainkannya Pembelajaran berasaskan permainan merupakan satu permainan dunia maya di mana gabungan bermain sambil belajar diterapkan dalam kalangan pelajar [5]. Bermain merupakan keseronokan dalam pendidikan awal kanak-kanak di mana dengan bermain, mereka dapat merasakan pengalaman tersendiri dalam pembelajaran [35]. Keseronokan yang dialami dalam bermain menyebabkan pelajar tidak merasakan mereka sedang belajar. Situasi ini dapat menjana kemahiran dan motivasi pelajar akan meningkat di mana ia dapat menarik minat para pelajar dan menjadikan sesuatu pembelajaran itu lebih bermakna dan berkesan [36.

Menurut Alias \& Ibrahim [37] dalam artikelnya yang bertajuk Keberkesanan Permainan Pendidikan 
Terhadap Pembelajaran Hukum Newton, penggunaan permainan pendidikan adalah selaras dengan model ARCS bagi merangsang pembelajaran. Empat komponen dalam model ARCS seperti Jadual 1.

Jadual 1. Model ARCS [38]

\begin{tabular}{ccl}
\hline BIL & KOMPONEN & \multicolumn{1}{c}{ PENERANGAN } \\
\hline 1 & $\begin{array}{c}\text { Perhatian } \\
\text { (Attention) }\end{array}$ & $\begin{array}{l}\text { Ciri-ciridalampermainanpendidikan } \\
\text { menyebabkanwujudperasaaningintahudandapatmenarikpe } \\
\text { rhatianpelajaruntukterusbermain. }\end{array}$ \\
\hline 2 & $\begin{array}{c}\text { Relevan } \\
(\text { relevant })\end{array}$ & $\begin{array}{l}\text { Membenarikanpelajarmempelajaripelbagaikemahiranbaru } \\
\text { dalam permainan pendidikan. }\end{array}$ \\
\hline 3 & $\begin{array}{c}\text { Keyakinan } \\
\text { (Confident) }\end{array}$ & $\begin{array}{l}\text { Menggunakan maklum balas dalam permainan } \\
\text { pendidikanagar dapat meningkatkan keyakinan pelajar } \\
\text { untuk mencapaimatlamatpermainan. }\end{array}$ \\
\hline 4 & $\begin{array}{c}\text { Kepuasan } \\
\text { (Satisfaction) })\end{array}$ & $\begin{array}{l}\text { Apabila pelajar dapat melalui sesuatu tahap cabaran } \\
\text { dalampermainanpendidikan, mereka akan mencuba tahap } \\
\text { cabaran yang seterusnya bagi mendapat kepuasan dalam } \\
\text { bermain. }\end{array}$ \\
\hline
\end{tabular}

Model ARCS adalah pendekatan penyelesaian masalah dalam mereka bentuk aspek motivasi persekitaran pembelajaran untuk merangsang dan mengekalkan motivasi pelajar untuk belajar [38].

\subsection{Penggunaan Teknologi dalam Pembelajaran Matematik}

Dalam era ini, terdapat pelbagai kajian mengenai kaedah dalam pembelajaran Matematik. Hal ini kerana, seiring dengan kemajuan yang telah dicapai oleh Malaysia, pelbagai usaha giat dilakukan bagi melakukan tranformasi dalam bidang pendidikan. Pendekatan yang berbeza wajar dilakukan dalam proses pengajaran dan pembelajaran bagi menarik minat murid untuk melibatkan diri dalam proses tersebut. Dalam kajian "Keberkesanan Permainan Interaktif dalam Mengatasi Masalah Kebimbangan terhadap Matapelajaran Matematik dikalangan Pelajar" yang dijalankan oleh Samsudin, Rosly, Japeri, Rahman dan Abdullah [39], bagi menilai tahap keberkesanan permainan interaktif dalam mengatasi masalah kebimbangan terhadap matapelajaran Matematik di kalangan pelajar, satu program yang terdiri daripada cerama motivasi, ceramah teknik belajar Matematik, ceramah "maths error" dan juga permainan interaktif telah dianjurkan. Ujian pra diedarkan sebelum ceramah bermula dan ujian pasca diedarkan selepas program tamat. Berdasarkan kajian tersebut, pelajar sangat tertarik dengan permainan interaktif dengan memberikan peratusan yang paling tinggi. Kajian itu menunjukkan pelajar masa kini lebih memilih permainan interaktif sebagai salah satu elemen baru untuk mereka mempelajari subjek Matematik.

Dalam kajian yang dilakukan oleh Richeal [40] yang bertajuk Keberkesanan Penggunaan Visualiser Terhadap Penyelesaian Soalan Matematik Berbentuk KBAT Bagi Murid Tingkatan 5, kaedah alat bantu pengajaran iaitu visualiser telah digunakan semasa proses pengajaran dan pembelajaran (P\&P) dalam menyelesaikan soalan-soalan Matematik yang berbentuk KBAT. Dalam kajian tersebut, penggunaan visualiser dalam proses pengajaran dan pembelajaran telah digunakan sebanyak tiga kali dalam seminggu dan setiapnya mengambil masa selama 40 minit. Hasil kajian itu mendapati bahawa penggunaan visualiser dalam proses $\mathrm{P} \& \mathrm{P}$ telah menjadikan pelajar lebih berminat, suka dan seronok untuk belajar dalam penyelesaian soalan Matematik berbentuk KBAT. Tujuan penggunaan teknologi adalah supaya pelajar lebih bermotivasikan diri untuk melibatkan diri dalam pembelajaran [41]. Visualiser dipilih dalam kajian ini kerana peranan sebagai teknologi pengajaran. Bruggen [42] ada menyatakan bahawa persekitaran pembelajaran akan menjadi lebih menyeronokkan dengan penggunaan teknologi.

\subsection{Kajian Terhadap Permainan Mudah alih Sedia Ada}

Beberapa permainan mudah alih yang sedia ada dan berkait dengan permainan mudah alih yang dibangunkan: 
1. Permainan Mudah Alih Multiplication Tables for Kids

2. Permainan Mudah Alih Toon Math: Endless Run and Math Games

3. Permainan Mudah Alih Math Games
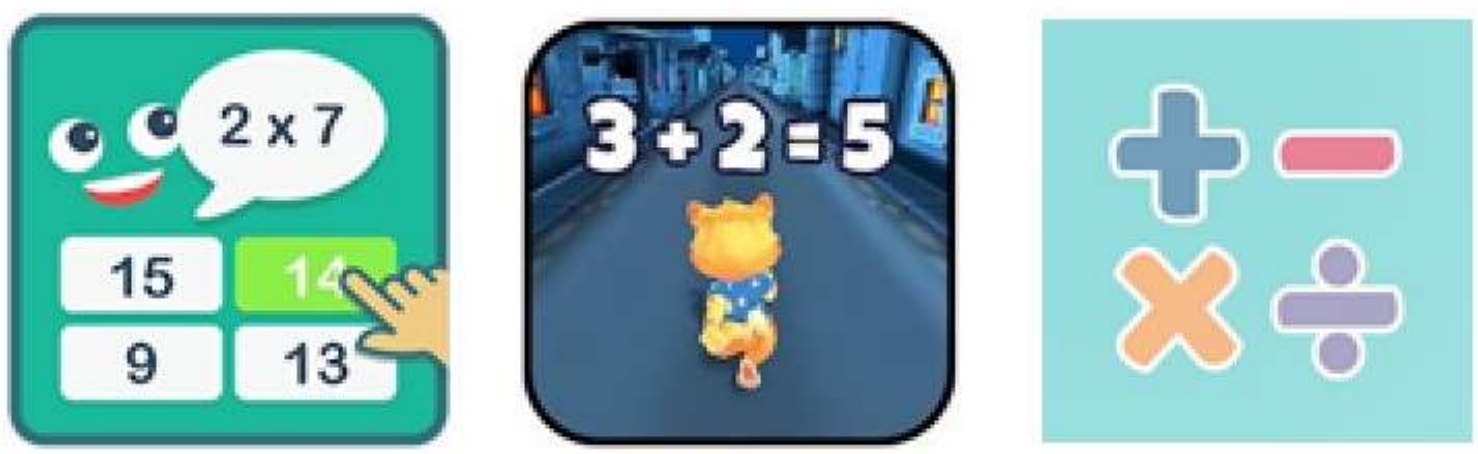

Rajah 1. Permainan Mudah Alih:

(a) Multiplication Tables for Kids

(b) Toon Math: Endless Run and Math Games

(c) Math Games

Jadual 2. Perbandingan Berdasarkan Kekurangan dan Kelebihan Permainan

\begin{tabular}{|c|c|c|}
\hline Permainan & Kelebihan & Kekurangan \\
\hline $\begin{array}{l}\text { Multiplication } \\
\text { TablesforKids }\end{array}$ & $\begin{array}{l}>\text { Teksmudah difahami } \\
\text { Kandungan yang disediakan } \\
\text { lebih } \\
\text { kepadapembelajaranberbandin } \\
\text { g hiburan }\end{array}$ & $\begin{array}{ll}> & \text { Imej dan warna yang } \\
\text { digunakan tidakmenarik } \\
\text { dan agak membosankan } \\
\text { untukkanak-kanak } \\
>\quad \text { Audio yang digunakan } \\
\text { tidak sesuai untukmenarik } \\
\text { perhatian kanak-kanak } \\
\text { keranamenggunakansuaraor } \\
\text { ang dewasa } \\
>\text { Tiadaanimasidantekstidak } \\
\text { menarik } \\
>\text { Tiadatutorial }\end{array}$ \\
\hline $\begin{array}{l}\text { Toon Math: } \\
\text { EndlessRunand } \\
\text { MathGame }\end{array}$ & $\begin{array}{l}\text { Grafikdanantaramukasangatm } \\
\text { enarik } \\
\text { Permainan yang agak } \\
\text { mencabar } \\
\text { keranamempunyaibanyakhala } \\
\text { ngan }\end{array}$ & $\begin{array}{l}>\text { Tiadabutangkeluar } \\
\text { Kurangelemenpembelajar } \\
\text { andanlebihkepada } \\
\text { hiburan }\end{array}$ \\
\hline $\begin{array}{l}\text { MathGa } \\
\text { mes }\end{array}$ & $\begin{array}{l}\text { Kandungan permainan lebih } \\
\text { kepadapembelajaranberbandin } \\
\text { ghiburan }\end{array}$ & $\begin{array}{ll}> & \text { Arahanyangdiberikantidakjelas } \\
& \text { Tekskecil dankurangmenarik } \\
& \text { Tiada suara } \\
& \text { Tiadatutorial }\end{array}$ \\
\hline
\end{tabular}


Jadual 3. Perbandingan Berdasarkan Ciri-ciri Elemen dalam Permainan

\begin{tabular}{ccccc}
\hline & $\begin{array}{c}\text { Multiplication } \\
\text { Tables for Kids }\end{array}$ & $\begin{array}{c}\text { Toon Math: } \\
\text { Endless Run and } \\
\text { Math Games }\end{array}$ & Math Games & Sifir Run \\
\hline Grafik & $\begin{array}{c}\text { Unsur grafik } \\
\text { terhad }\end{array}$ & $\begin{array}{c}\text { Banyak unsur } \\
\text { grafik }\end{array}$ & $\begin{array}{c}\text { Banyak unsur } \\
\text { grafik }\end{array}$ & $\begin{array}{c}\text { Banyak unsur } \\
\text { grafik }\end{array}$ \\
\hline Audio & Ada & Ada & Tiada & Ada \\
\hline Video & Tiada & Ada & Tiada & Ada \\
\hline Teks & Teks ringkas & $\begin{array}{c}\text { Teks ringkas dan } \\
\text { menarik }\end{array}$ & $\begin{array}{c}\text { Banyak } \\
\text { elemen teks }\end{array}$ & $\begin{array}{c}\text { Kurang elemen } \\
\text { teks }\end{array}$ \\
\hline Animasi & Animasi 2D & Animasi 3D & Animasi 2D & Animasi 2D \\
\hline Navigasi & Bagus & Kurang Bagus & Bagus & Bagus \\
\hline Interaksi & Tiada interaktif & Sangat Interaktif & Sederhana & Sangat Interaktif \\
\hline
\end{tabular}

\section{Metodologi Kajian}

\subsection{Kaedah dan reka Bentuk Kajian}

Kaedah dan reka bentuk kajian yang telah digunakan dalam kajian ini adalah berbentuk deskriptif dengan menggunakan kaedah tinjauan. Reka bentuk ini digunakan untuk melihat dan menilai permasalahan pelajar dalam menyelesaikan operasi darab dan tahap penguasaan pelajar dalam kemahiran meningat sifir. Melalui kaedah ini, pengkaji menggunakan teknik temu bual. Kaedah ini membolehkan pengkaji mendapatkan maklumat penyelidikan secara langsung daripada subjek. Pengkaji menemu bual seorang guru Matematik dan beberapa orang murid dari Sekolah Rendah Kebangsaan Paya Panjang, Muar Johor bagi mendapatkan maklumat untuk menjawab segala persoalan yang timbul dalam fasa analisis. Pengkaji melibatkan beberapa orang murid dalam temu bual ini kerana pengkaji berpendapat bahawa idea spontan yang diberi oleh pelajar mungkin berguna untuk menyokong dapatan kajian. Dalam kajian ini, pengkaji menggunakan teknik temu bual berstruktur. Pengkaji merakam sesi temu bual yang dilakukan dan data telah dikumpul melalui transkrip suara dari sesi temu bual tersebut.

\subsection{Sampel Kajian}

Pemilihan sampel kajian tertumpu kepada guru Matematik sekolah rendah. Pemilihan sampel ini didasarkan atas fakta bahawa responden telah mempunyai pengetahuan dan pengalaman yang berkaitan dengan permasalahan dalam operasi darab dan tahap penguasaan sifir dikalanganmurid. Selain itu, sampel kajian juga telah melibatkan seramai 20 orang responden di kalangan ibu bapa dan pelajar dalam fasa penilaian selepas aplikasi siap dibangunkan.

\subsection{Prosedur Kajian}

Reka bentuk dalam sesuatu aplikasi yang berasaskan pendidikan merupakan elemen utama dan terpenting dalam menjayakan proses pengajaran dan pembelajaran yang ingin dicapai mengikut objektif dan matlamat yang dinyatakan. Model-model reka bentuk pengajaran dalam aplikasi ini mestilah direka bentuk berpandukan teori-teori pembelajaran seperti teori pembelajaran behaviorisme, kognitivisme dan konstruktivisme. Dalam kajian ini, pengkaji ingin membangunkan sebuah mudah alih game yang berasaskan pendidikan bagi subjek Matematik yang bertemakan sifir yang mensasarkan penggunanya dari kalangan murid di peringkat sekolah rendah.

Untuk memastikan proses pengajaran dan pembelajaran dalam mudah alih game ini berkesan dan membolehkan murid memperolehi kemahiran, pengetahuan dan sikap yang diharapkan serta menambah minat pelajar, maka ianya perlu kepada satu aplikasi yang reka bentuknya didasari kepada teori dan model yang tepat dan sistematik menepati kehendak dan keperluan murid- murid. Hal ini kerana, dalam proses pengajaran, pelbagai teori, strategi serta pendekatan yang tertentu perlu digunakan dalam memastikan objektif serta matlamat pengajaran berjaya dicapai. Selain itu, menurut Dick \& Reiser [43], tujuan diadakan reka bentuk pengajaran ialah untuk mengesyorkan kaedah pengajaran yang optimum yang boleh mengubah pengetahuan pelajar, kemahiran dan afektif pelajar.

Ada beberapa model yang banyak digunakan dalam fasa pembangunan sebuah aplikasi, iaitu ADDIE 
[44] [45] [46], Evolutionary Prototype Model [47], Rapid Application Development [18], Rapid Prototyping [19], waterfall [48], Multimedia Development Life Cycle [49] [50], Prototyping [51] [52], Object Oriented Analysis and Design [53].

Dalam penyelidikan ini, pengkaji menggunakan model ADDIE memandangkan aplikasi yang telah dibangunkan merupakan aplikasi pembelajaran. Model ini menjadi pilihan pengkaji kerana proses yang dikemukan oleh model ADDIE dilihat amat jelas dan berorientasikan sistem dalam menghasilkan satu reka bentuk mudah alih game berasaskan pendidikan yang baik. Model ADDIE merupakan pendekatan yang berstruktur dan berterusan. Model ini mempunyai proses iteratif atau proses berulang yang boleh diimplementasi dalam pembangunan perisian.

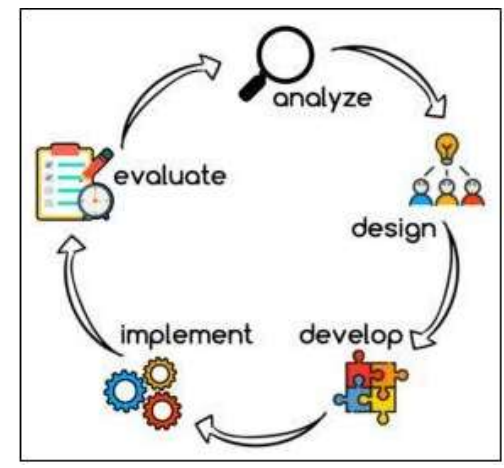

Rajah 2. Proses dalam Mereka Bentuk Berdasarkan Teori Model ADDIE

\subsection{Carta Alir}

Rajah 3 menunjukkan aliran kerja yang dilakukan oleh pengkaji dalam fasa reka bentuk aplikasi permainan mudah alih Sifir Run.

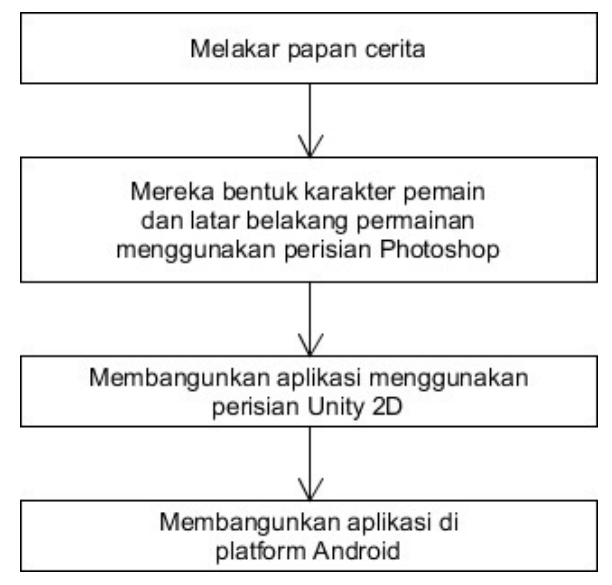

Rajah 3. Carta Alir Reka Bentuk Aplikasi

Seperti yang ditunjukkan pada Rajah 3, pengkaji membuat sebuah papan cerita terlebih dahulu bagi mengenalpasti lakaran awal tentang bagaimana aplikasi dibangunkan. Selepas itu, pengkaji menggunakan papan cerita tersebut sebagai panduan dalam mereka bentuk karakter pemain dan latarbelakang permainan. Pengkaji menggunakan perisian Adobe Photoshop untuk mereka bentuk pemain dan latar belakang permainan. Begitu juga dengan butang yang terdapat dalamaplikasi tersebut. Selepas siap mereka bentuk antaramuka permainan, pengkaji meneruskan proses pembangunan dengan membangunkan aplikasi menggunakan perisian Unity 2D. Dan akhir sekali, pengkaji memasang aplikasi yang siap dibangunkan di platform Android. 


\section{Dapatan Kajian dan Analisis}

\subsection{Reka Bentuk Aplikasi}

Paparan antaramuka laman utama yang dibangunkan memaparkan tajuk aplikasi iaitu Sifir Run. Dalam paparan ini juga terdapat beberapa butang yang mempunyai fungsi tersendiri iaitu butang Play, Exit, butang suara dan juga info mengenai pengkaji. Butang Play akan membawa pemain ke paparan seterusnya iaitu paparan peringkat dalam permainan Sifir Run. Butan Exit untuk keluar dari permainan, butang suara untuk mematikan suara permainan dan butang info untuk memaparkan maklumat mengenai pengkaji.

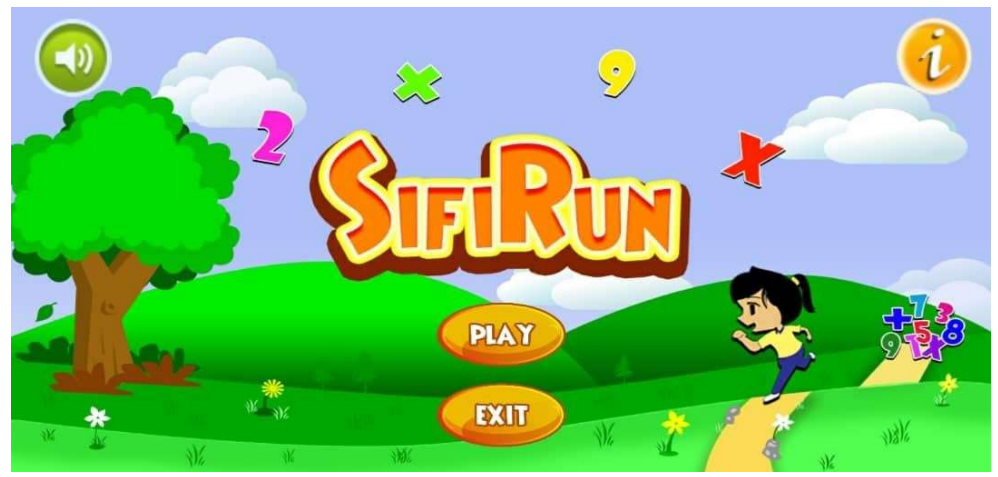

Rajah 4. Antaramuka Laman Utama

Paparan pada Rajah 5 merupakan paparan antaramuka butang Exit. Sekiranya pemain menekan butang No, pemain akan kembali ke paparan laman utama dan sekiranya pemain menekan butang Yes, pemain akan keluar dari permainan.

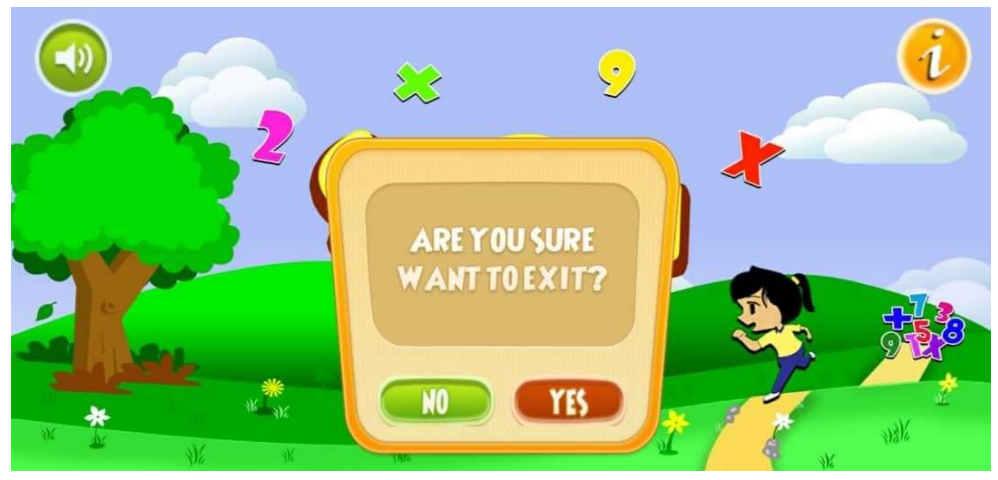

Rajah 5. Antaramuka Keluar

\subsection{Maklum Balas Responden}

Kajian ini menggunakan kaedah statistik deskripsi dan Jadual 4 menunjukkan demografi responden.Jadual 5 menunjukkan dapatan yang diperoleh berdasarkan penilaian borang soal selidik daripada 20 orang responden terhadap aplikasi permainan mudah alih Sifir Run.

Menerusi Jadual 5, bagi pernyataan yang pertama, majoriti responden sangat bersetuju dengan pernyataan tersebut iaitu seramai 12 orang, manakala lima orang setuju dan hanya tiga orang untuk skala natural. Data ini menunjukkan bahawa, aplikasi yang dibina tidak sukar untuk digunakan. 
Jadual 4. DemografiResponden

\begin{tabular}{ccccc}
\hline \multirow{2}{*}{ Jolongan } & \multicolumn{2}{c}{ Lelaki } & \multicolumn{2}{c}{ Perempuan } \\
\cline { 2 - 5 } & $f$ & $(\%)$ & $f$ & $(\%)$ \\
\hline Ibu Bapa & 3 & 15 & 7 & 35 \\
\hline Pelajar & 4 & 20 & 6 & 30 \\
\hline
\end{tabular}

Seterusnya, bagi pernyataan kedua, seramai 10 orang sangat bersetuju bahawa aplikasi ini menyeronokkan. Selebihnya, lima orang responden mengatakan setuju dan dua orang natural dengan pernyataan tersebut. Hal ini menunjukkan, majoriti responden menikmati penggunaan aplikasi permainan mudah alih Sifir Run.Manakala, 12 orang responden bersetuju dan lapan orang responden sangat bersetuju dengan pernyataan ketiga. Seterusnya bagi pernyataan keempat, terdapat dua orang responden tidak bersetuju, 10 orang natural, lima orang bersetuju dan tiga orang sangat setuju bahawa aplikasi ini mengukuhkan pengetahuan sedia ada.

Jadual 5. PenilaianRespondenTerhadapAplikasi

\begin{tabular}{|c|c|c|c|c|c|c|}
\hline \multirow{2}{*}{ NO } & \multirow{2}{*}{ ITEM } & \multicolumn{5}{|c|}{ Peratus(\%)/f } \\
\hline & & STS & TS & $\mathbf{N}$ & $\mathbf{S}$ & SS \\
\hline S1 & Aplikasiinimudahdigunakan & 0 & 0 & $15(3)$ & $25(5)$ & $60(12)$ \\
\hline $\mathbf{S 2}$ & $\begin{array}{l}\text { Pembelajaranmenggunakan } \\
\text { aplikasi inimenyeronokkan }\end{array}$ & 0 & 0 & $10(2)$ & $40(8)$ & $50(10)$ \\
\hline $\mathbf{S 3}$ & $\begin{array}{l}\text { Aplikasi } \\
\text { dipersembahkandengan } \\
\text { gayamudahdanmenarik }\end{array}$ & 0 & 0 & 0 & $60(12)$ & $40(8)$ \\
\hline S4 & $\begin{array}{l}\text { Aplikasiinimengukuhkan } \\
\text { pengetahuan sediaada }\end{array}$ & 0 & $10(2)$ & $50(10)$ & $25(5)$ & $15(3)$ \\
\hline S5 & $\begin{array}{l}\text { Aplikasiiniberkaitandengan } \\
\text { pembelajaran disekolah rendah }\end{array}$ & 0 & 0 & 0 & $20(4)$ & $80(16)$ \\
\hline S6 & $\begin{array}{l}\text { Aplikasiinibolehdigunakan } \\
\text { dalamkehidupanseharian }\end{array}$ & 0 & 0 & 0 & $35(7)$ & $65(13)$ \\
\hline S7 & $\begin{array}{l}\text { Aplikasi ini } \\
\text { sesuaidigunakansebagaibahanp } \\
\text { embelajaran }\end{array}$ & $15(3)$ & $20(4)$ & $40(8)$ & $10(2)$ & $15(3)$ \\
\hline S8 & $\begin{array}{l}\text { Aplikasiinimemerlukan } \\
\text { masa yang singkat } \\
\text { untukdikuasai }\end{array}$ & 0 & $10(2)$ & $25(5)$ & $35(7)$ & $30(6)$ \\
\hline S9 & $\begin{array}{l}\text { Aplikasi ini } \\
\text { bolehdigunakantanpabantuanor } \\
\text { ang lain }\end{array}$ & 0 & $10(2)$ & $20(4)$ & $40(8)$ & $30(6)$ \\
\hline S10 & $\begin{array}{l}\text { Aplikasiinimeningkatkankema } \\
\text { hiranpenggunadalammenghafal } \\
\text { sifir }\end{array}$ & 0 & $15(3)$ & $25(5)$ & $30(6)$ & $30(6)$ \\
\hline
\end{tabular}

STS=SangatTidak SetujuTS=Tidak SetujuN=NeutralS=SetujuSS=SangatSetuju

Bagi pernyataan "aplikasi ini berkaitan dengan pembelajaran di sekolah rendah, kesemua responden setuju dan sangat setuju dengan pernyataan tersebut. Hal ini menunjukkan bahawa kandungan aplikasi ini tidak tersasar dari pembelajaran di sekolah rendah.Aplikasi ini boleh disimpulkan agak mudah untuk dikuasai oleh responden berdasarkan data yang dikumpul iaitu seramai dua orang tidak bersetuju, lima orang natural, tujuh orang bersetuju dan lima orang sangat bersetuju dengan pernyataan "aplikasi ini memerlukan masa yang singkat untuk dikuasai”.

Seterusnya, data menunjukkan bahawa dua orang tidak bersetuju, empat orang memberikan skala 
natural, lapan dan enam orang untuk setuju dan sangat setuju untuk pernyataan "aplikasi ini boleh digunakan tanpa bantuan orang lain".Akhir sekali, skala setuju dan sangat setuju berkongsi data yang sama iaitu seramai enam orang memilih skala tersebut manakala selebihnya iaitu lima dan tiga orang memilih natural dan tidak setuju untuk pernyataan "aplikasi ini meningkatkan kemahiran pengguna dalam menghafal sifir".

\section{Kesimpulan}

Secara keseluruhannya, dapat disimpulkan bahawa aplikasi permainan mudah alih Sifir Run ini telah mendapat responden yang agak positif dikalangan pelajar dan ibu bapa. Namun, pengkaji berpendapat bahawa aplikasi ini kurang mencapai matlamat kajian iaitu untuk meningkatkan kemahiran menghafal sifir berdasarkan data yang dikumpul. Terdapat beberapa kelemahan dan kekurang dalam aplikasi ini yang perlu ditambahbaik dan perbaiki bagi mencapai matlamat pembangunan.

Aplikasi permainan mudah alih Sifir Run, mempunyai antaramuka yang menarik dan tidak membosankan. Animasi dan audio yang terdapat dalam permainan mudah alih ini jugak memainkan peranan yang penting. Hal ini menyebabkan pengguna merasai keseronokan untuk menggunakan permainan mudah alih ini. Selain itu, aplikasi ini membolehkan pengguna untuk belajar sambil bermain. Aplikasi ini juga menggunakan permainan mudah alih yang berkonsepkan endless run atau larian tidak berkesudahan yang memudahkan pengguna kerana tidak perlu mengawal pergerakan pemain. Pengguna hanya perlu menekan skrin bagi membolehkan pemain melakukan lompatan.

Kelemahanpermainan mudah alih ini adalah permainan memfokuskan kepada satu jenis permainan sahaja dan setiap tahap hanya mengulangi corak permainan yang sama. Aplikasi ini hanya memaparkan jawapan bagi setiap sifir dan menyebabkan pengguna kurang memahami corak permainan diawal permainan. Selain itu, arahan permainan dalam aplikasi ini kurang efektif kerana pengguna tidak boleh melangkau atau mempercepatkan arahan. Pengkaji juga mendapati bahawa permainan yang direka dalam aplikasi ini kurang efektif bagi meningkatkan kemahiran pengguna dalam menghafal sifir berdasarkan skor bagi item "Aplikasi ini meningkatkan kemahiran pengguna dalam menghafal sifir" dalam borang soal selidik.

Selepas melalui proses penilaian, terdapat beberapa cadangan penambahbaikan yang boleh dilakukan oleh pengkaji bagi mengatasi kelemahan dalam aplikasi ini. Antara cadangan tersebut ialah:

1. Paparan soalan

Aplikasi ini mempunyai corak permainan yang tidak begitu jelas iaitu pemain hanya perlu melompat untuk mengambil jawapan yang betul mengikut tahap yang mereka pilih iaitu sekiranya pengguna memilih tahap sifir dua, jawapan yang perlu diambil dalam permainan tersebut hanyalah jawapan sifir dua. Corak permainan ini agak sukar untuk difahami lebih-lebih lagi bagi murid sekolah rendah. Oleh itu, pengkaji boleh melakukan penambahbaikan dengan memaparkan soalanterlebih dahulu dan diikuti dengan pemain mengutip jawapan yang betul bagi soalan tersebut. Penambahbaikan ini lebih efektif bagi mencapai matlamat pembangunan aplikasi.

2. Menambah fungsi mempercepatkan arahan

Dalam aplikasi ini terdapat arahan permainan yang menunjukkan cara- cara untuk bermain sebelum memulakan permainan. Namun begitu, arahan ini mengambil masa yang agak lama dan tidak boleh dipercepatkan. Pengkaji boleh menambah fungsi yang dapat mempercepatkan arahan permainan agar pengguna tidak merasa jemu menunggu arahan permainan tamat dimainkan.

3. Menambah tahap dalam permainan

Aplikasi permainan mudah alih ini mempunyai corak permainan yang sama dalam setiap tahap. Oleh itu, penambahbaikan boleh dilakukan dalam permainan ini dengan menambah tahap mudah, sederhana dan sukar dan corak permainan yang berbeza dalam setiap tahap tersebut. Hal ini dapat menambah keseronokan pengguna ketika menggunakan aplikasi ini.

\section{Rujukan}

[1] K. Aphra and I. D. James, Online Games in the International Encyclopaedia of Communication. Oxford: Wiley, 2015.

[2] M. I. M. Hayati, M. Y. M. Nasir, M. and L. Farhana, "Pendekatan Melalui Reka Bentuk Permainan Digital dalam Proses Pengajaran dan Pembelajaran Kanak-Kanak: Isu dan Cabaran," in 5th International Conference on Education of Adi Buana, Surabaya, 24 Mei 2014, pp. 1- 10. 
[3] S. M. Kangungu and M. H. Mohamad Yatim, "Teaching Programming Using the RobotBased Learning Approach", International Journal of Artificial Intelligence, vol. 7, no. 2, pp. 22-28, Dec. 2020.

[4] M. M. N. Azli, M. D. H. Anuar, Z. A. A. Nazeer, M. S. N. Muizz and A. I. Fadzliana, "Kesan Permainan Digital dalam Pendidikan," in International Conference on Information Technology \& Society, Kuala Lumpur, 8-9 June 2015, pp. 292-297.

[5] N. Muhamad, J. Harun, M. A. Z. M. Zakariam and S. M. Salleh, "Implementation of Game-Based Learning to Enhance Student's Problem Solving Skills," Journal of Computational and Theoretical Nanoscience, vol. 24, no. 6, pp. 4474-4477, 2018.

[6] P. A. Ertmer, A. T. Ottenbreit-leftwich, O. Sadik, E. Sendurur and P. Sendurur, "Computers \& Education Teacher Beliefs and Technology Integration Practices," A Critical Relationship. Computers \& Education, vol. 54, no. 2, pp. 423-435, 2012.

[7] H. S. Hsiao, C. S. Chang, C. Y. Lin and P. M. Hu, "Development of Children's Creativity and Manual Skills Within Digital Game-Based Learning Environment," Journal of Computer Assisted Learning, vol. 30, no. 4, pp. 377-395, 2014.

[8] A. Z. Zakaria, H. Hassan, H. Halim, W. A. N. Wan Idris, M. A. Abdullah Zawawi, and N. F. Mansor, "Learning Mathematics: One Minute", International Journal of Multimedia and Recent Innovation, vol. 2, no. 2, pp. 76-86, Sep. 2020.

[9] W. A. N. Wan Idris, H. Halim, H. Hassan, and I. Y. Panessai, "GENIUS KIDS: Learn to Count through Games", International Journal of Multimedia and Recent Innovation, vol. 1, no. 1, pp. 117, Sep. 2019.

[10] H. Halim, W. A. N. Wan Idris, H. Hassan, and I. Y. Panessai, "Learning Logic Gate through 7Gates", International Journal of Multimedia and Recent Innovation, vol. 2, no. 1, pp. 1-10, Mar. 2020.

[11] Yong, K. Yeoh, Cham, J. Eng and Chen, I. Joo, Matematik Tingkatan 4. Kuala Lumpur: Pustaka Alhas (M) Sdn. Bhd, 2001.

[12] S. M. Meerah, Strategi Pengajaran Untuk Meningkat Prestasi Sains dan Matematik. Seminar Kebangsaan Pendidikan Sains \& Matematik. Selangor: Universiti Kebangsaan Malaysia, 1996.

[13] M. S. N. M. Sukri and Z. H. Shabdin, Meningkatkan Penguasaan Murid Dalam Operasi Darab Menggunakan Kaedah Garis Silang (Kaedah Alternatif). Pinang: Institut Pendidikan Guru Kampus Pulau Pinang, 2013.

[14] Duniapcoid, "Kartun: Pengertian, Sejarah, Perkembangan, Jenis, Cirinya," Dunia pendidikan [Online]. Available: https://duniapendidikan.co.id/kartun/. [Accessed: April 2021].

[15] N. H. Sukri, S. Sadimon, Aplikasi Permainan Pembelajaran untuk Kanak-kanak in Inovasi di dalam Teknologi dan Aplikasi Komputeran. Johor: Universiti Teknologi Malaysia, 2017.

[16] Ismail, N. Iksan, S. K. Subramaniam, A. S. Abdulbaqie, S. K. Pillai, I. Y. Panessai, "Usefulness of Augmented Reality as a Tool to Support Online Learning," Jurnal Ilmiah Teknik Elektro Komputer dan Informatika (JITEKI), vol. 7, no. 2, August 2021, pp. 277-285. DOI: 10.26555/jiteki.v7i2.21133

[17] M. A. Ishak, M. R. Kosnan, and N. F. Zakaria, "Build IoT through Virtual Reality", International Journal of Multimedia and Recent Innovation, vol. 2, no. 1, pp. 11-25, Mar. 2020.

[18] N. A. A. Edyanto, S. Z. Ramli, N. A. N. Ibharim, S. A. Zahari, and M. A. Abdullah Zawawi, "Learn Idioms Using Augmented Reality", International Journal of Multimedia and Recent Innovation, vol. 3, no. 1, pp. 11-16, Mar. 2021.

[19] Z. Zainal Abidin and M. A. Abdullah Zawawi, "OOP-AR: Learn Object Oriented Programming Using Augmented Reality", International Journal of Multimedia and Recent Innovation, vol. 2, no. 1, pp. 60-75, Mar. 2020.

[20] N. A. N. Ibharim, S. Z. Ramli, S. A. Zahari, N. A. A. Edyanto, and M. A. Abdullah Zawawi, "Learning History Using Augmented Reality", International Journal of Multimedia and Recent Innovation, vol. 3, no. 1, pp. 1-10, Mar. 2021.

[21] S. F. Sezali, A. M. Radzuan, N. I. Mohd Shabudin, and R. A. Afendi, "POCKET MALAYSIA: Learning About States in Malaysia Using Augmented Reality", International Journal of Multimedia and Recent Innovation, vol. 2, no. 1, pp. 45-59, Mar. 2020.

[22] C. Anam and M. I. Priharto, "Snakes and Ladders Board Game Table Design to Develop Cognitive, Social and Tactual Perception Skills in Blind Children", International Journal of Recent Technology and Applied Science, vol. 3, no. 2, pp. 58-66, Sep. 2021. 
[23] I. Y. Panessai, N. Iksan, S. A. Zahari, A. S. Abdulbaqi, M. M. Lakulu, M. R. Husin, H. Ahmad, H. AbdArif and Pratiwi, "Learning Internet of Things by using Augmented Reality," 2021 5th International Conference on Virtual and Augmented Reality Simulations, Melbourne (Australia), March 2021.

[24] S. K. Pillai, N. Iksan, H. A. Arif, I. Y. Panessai, A. S. Abdulbaqie, Ismail, "Kemudahan Penggunaan Augmented Reality sebagai Alat Bantu Pembelajaran Online bagi Meningkatkan Kinerja dan Prestasi Siswa Dalam Seni Ukiran Kayu”, Journal of Engineering, Technology, and Applied Science, vol. 3, no. 2, pp. 48-57, Aug. 2021.

[25] E. Adams, Fundamentals of Game Design 2nd Edition. Berkeley: New Riders Publishing, 2010.

[26] S. Margaretha, "Platform Game," 2013 [Online]. Available: http://shipo-margareth.blogspot. co.id/2013/01/platform-game.html. [Accessed: June 2021].

[27] P. S. G. Galehantomo, "Platform Comparison between Games Console, Mudah alih Games and PC Games," Journal of Information System, vol. 2, no. 1, pp. 23-26, 2015.

[28] N. J. A. Halim, "Penggunaan Permainan Digital di Dalam Proses Pengajaran," 2019 [Online]. Available: http://nurinjazlinahalim.blogspot.com/2015/05/penggunaan-permainan-digital-di-da lam.html [Accessed: April 2021]

[29] M. R. Husin, H. Ahmad, I. Y. Panessai, N. A. Majid, A. L. Sulam, A. Lokman, "Inductive Instructional Approach, Career Aspiration and Noble Values in History," International Journal of Evaluation and Research in Education, vol. 9, no. 1 pp. 162-167, Mar 2020.

[30] N. M. Hassan, N. A. N. F. M. Noor, Y. A/P Thasarathan, Q. N. Zainudin, N. S. A. Zainuri, N. R. N. M. Rizuaden, N. A. M. Fauzi, N. Tumin, and N. A. S. M. Jefri, "Perspektif Guru Terhadap Kemahiran Berfikir Aras Tinggi dalam Kalangan Pelajar", Journal of Humanities and Social Sciences, vol. 3, no. 2, pp. 50-56, Aug. 2021.

[31] N. Abdul Rahim, N. A. Meor Fadzir, N. A. H. Zaimal, F. F. Arias Yahaya, Z. I. Zainol, and M. R. Husin, "Implikasi Gaya Pembelajaran Koperatif Subjek Sains Bagi Murid Tahap Dua di Sekolah Kebangsaan Bandar Baru Rawang", Journal of Humanities and Social Sciences, vol. 3, no. 2, pp. 57-66, Aug. 2021.

[32] C. Ifeakor and A. I. Odo, "Analysis of the Marxist Theory on the Abolition of State: Its Implication to Nigeria Educational System", Journal of Humanities and Social Sciences, vol. 2, no. 2, pp. 62-68, Aug. 2020.

[33] N. M. Shahril Khuzairi, M. S. Sidhu, and Z. Che Cob, "Learning Analytics and Teaching Analytics: The Similarities and Differences", International Journal of Humanities, Management and Social Science, vol. 3, no. 2, pp. 52-58, Dec. 2020.

[34] L.M. Rais, Aplikasi Game Math Race Berbasis Android. Universiti Negeri Alauddin, Makassar, 2017.

[35] A. Norazli and J. Ahmad, "Peranan Game-Based Learning Dalam Pembelajaran Bagi Meningkatkan Prestasi Murid Linus," in International Seminar on Global Education II: Education Transformation Toward a Develop Nation, 2014.

[36] C. Perrotta, G. Featherstone, H. Aston, and E. Houghton, Game-based Learning: Latest Evidence and Future Directions. Slough: NFER, 2013.

[37] S. N. Alias and F. Ibrahim, "Keberkesanan Permainan Pendidikan Terhadap Pembelajaran Hukum Newton: The Effectiveness of Educational Games on Newton's Laws Learning," Journal of Nusantara Studies, vol. 2, no. 1, pp. 71-85, 2017.

[38] J. M. Keller, "Development and Use of the ARCS Model of Motivational Design," Journal of Instructional Development, vol. 10, no. 3, pp. 2-10, 1987.

[39] N. Samsudin, W. N. W. M. Rosly, A. Z. U.- S. M. Japeri, S. M. A. Rahmn, and S. S. S. Abdullah, "Keberkesanan Permainan Interaktif dalam Mengatasi Masalah Kebimbangan terhadap Matapelajaran Matematik di kalangan Pelajar," International Academic Research Journal of Social Science, vol. 3, no. 1, pp. 202-207, 2017.

[40] P. Richeal, Keberkesanan Penggunaan Visualiser Terhadap Penyelesaian Soalan Matematik Berbentuk KBAT Bagi Murid Tingkatan 5 in Kajian Tindakan Akademik SMK Segama, Lahad Datu, 2015.

[41] M. Granito, "The Effect of Technology on Student's Motivation and Knowledge Retention," in NERA Conference Proc, no 117, 2012.

[42] J. V. Bruggen, "Theory and practice of Online Learning," British Journal of Educational Technology, vol. 36, pp. 111-112, 2005. doi:10.1111/j.1467-8535.2005.00445_1.x. 2005.

[43] W. Dick and R. A. Reiser, Planning Effective Instruction. United States: Prentice Hall, 1989. 
[44] N. H. Rahani, A. A. Bilong, M. R. Suruji, and I. Y. Panessai, "Learning Logic Gates Using Augmented Reality", International Journal of Multimedia and Recent Innovation, vol. 2, no. 1, pp. 26-44, 22 Mar 2020.

[45] M. Wedel, E. Bigné, and J. Zhang, "Virtual and augmented reality: Advancing research in consumer marketing", International Journal of Research in Marketing, vol. 37, no. 3, pp. 44-65, Sep 2020.

[46] N. A Ibharim, S. Z. Ramli, S. A. Zahari, N. A. Edyanto, and M. A. Zawawi, "Learning History Using Augmented Reality", International Journal of Multimedia and Recent Innovation, vol. 3, no. 1, pp. 1-10, 14 Mar 2021.

[47] A. Ismail, "An Early Development Process of an Augmented Reality-Based Healthy Diet Tool Prototype”, International Journal of Multimedia and Recent Innovation, vol. 26, no. 22, pp. 96101, Sep 2020

[48] F. D. Putra, J. Riyanto, and A. F. Zulfikar, "Rancang Bangun Sistem Informasi Manajemen Aset pada Universitas Pamulang Berbasis WEB", Journal of Engineering, Technology, and Applied Science. vol. 2, no. 1, pp. 32-50, 6 Apr 2020.

[49] F. Mantiri, "Multimedia and Technology in Learning", Universal Journal of Educational Research. vol. 2, no. 9, pp. 589-92, 2014.

[50] M. Bernarducci, "Multimedia for Learning: Methods and Development -Book Review", European Journal of Education Studies, 16 March 2017.

[51] N. F. Zakaria, Z. Z. Abidin, M. A. Zawawi, and S. N. Shuhada, "Bloodbuddy: a Tracking System for Blood Donor Using GPS", Journal of Engineering, Technology, and Applied Science. vol. 2, no. 2, pp. 86-102, 30 Aug 2020.

[52] N. H. Hasbullah and N. A. Noor, "Sistem Temujanji Interaktif Berasaskan WEB", Journal of Engineering, Technology, and Applied Science, vol. 2, no. 3, pp. 110-7, 17 Dec 2020.

[53] M. Olva, R. D. Permatasari, S. Majid, P. Syair, and A. Suganda, "Pemanfaatan Dasbor pada Pemantauan Data Transaksi Penjualan", Journal of Engineering, Technology, and Applied Science, vol. 3, no. 1, pp. 1-5, 14 Apr 2021. 